JPH: Jurnal Pembaharuan Hukum

Volume 8, Number 1, April 2021

\title{
ISM-CODE AS A LEGAL PROTECTION OF USE SHIPS ARE NOT CONFORT WITH MARINE STANDARD IN INDONESIA
}

\author{
Anirut Chuasanga \\ Fatoni University, Thailand \\ anirut2458@gmail.com \\ Ong Argo Victoria \\ International Islamic University Malaysia (IIUM), Malaysia \\ argovictoriaupin@gmail.com
}

\begin{abstract}
Transportation in general in Indonesia is facing many challenges, but all possibilities that will occur can be anticipated by structuring a more resilient national transportation system. This study aims to determine and understand the application of the ISM-Code to be used as legal protection from the use of ships that are not of marine standards. The research method used is the normative research method, which is a legal writing method that aims to obtain library legal materials by collecting and analyzing legal materials related to the problem. The results of this study are, first. In the application of the ISM-Code it is used as a legal protection from the use of ships that are not standard marine standards. There are still many shipping companies that issue policies that are not standard ISM-Code or do not meet the elements of Article 9 of the Minister of Transportation Number 45 of 2012 concerning Ship Safety Management Systems. And secondly the ISM-Code Required as Legal protection from the use of ships that do not meet maritime standards is the form of legal protection contained in the ISM-Code.
\end{abstract}

Keywords: International Safety Management Code, Legal protection, Marine Law.

\section{A. INTRODUCTION}

In any job, there is always a risk that arises in carrying out actions to fulfill the responsibilities for that job. The risk can be in the form of a small accident can even be in the form of a big accident (severe). The Work Safety Management System, both work safety on land, in the ground, on the surface of the water, in the water, in the air and wherever the work is carried out, there must always be a company that oversees it to provide policies in terms of the Work Safety Management System. The work safety implementation policy aims to create a culture of occupational safety and health (K3) in the workplace by 
involving companies, workers, working conditions and environment in order to prevent and reduce occupational accidents and diseases ${ }^{1}$.

Indonesia as an archipelagic country is an inseparable unity between land, sea and air. Physically, the sea is a real divider between islands from one another. Therefore, transportation is needed to reach other islands, from a marine perspective, it is a ship. In Article 310 KUHD states "Sea Ships are all ships that are used for shipping at sea or that are benefited for it". As a system, sea transportation, which is part of the National Transportation System, is supported by elements of sea transportation, port, shipboard marine activities, navigation and guarding and rescue that interact in an integrated manner in order to realize the availability of effective and efficient sea transportation. Transportation in general in Indonesia is facing many challenges, but all the possibilities that will occur can be anticipated with a more resilient National Transportation System Arrangement (SISTRANAS). This resilience cannot be separated from the supervision of three things, namely natural, human and technical resources ${ }^{2}$.

Due to weaknesses in monitoring the management of the marine transportation system in Indonesia. So Indonesia is facing sea transportation accidents. The International Safety Management Code (ISM-Code) is a standard for international safety management regulations for the safety and security of ship operations and prevention of pollution to the marine environment established by the IMO Maritime Safety Council. The purpose of the ISM-Code is to ensure safety at sea, prevent accidents and loss of human life and avoid damage to the environment, especially the marine environment and loss of property. The company must state in writing its policy (policy) regarding the safety and protection of the maritime (marine) environment and ensure that everyone in the company knows and understands it. ${ }^{3}$.

The provisions of Article 169 Part Seven of Act No. 17 Year 2008 concerning Shipping, it is clear that the company must meet the ISM-Code requirements in operating ships at sea or for the company operating the ship. The link here is on the embodiment of the ISM-Code policy itself. The continued regulation of Article 169 of Act No. 17 of 2008 concerning Shipping, is manifested in the form of a separate statutory regulation that specifically regulates ISM-Code. This manifestation is in the form of Minister of Transportation Regulation number 45 of 2012 concerning Ship Safety Management ${ }^{4}$.

1 Kit Fai Pun, Richard C. M. Yam, and Winston G. Lewis, Safety Management System Registration in the Shipping Industry, International Journal of Quality \& Reliability Management; Volume 20, Issue 6, 2002

2 Nina Nurhasanah, Asmar Joni, and Nur Shabrina, Perception of Crew and Management in the Implementation of ISMCode for Shipping Safety and Protection of the Marine Environment, National Multi Discipline Seminar and Call For Papers, Stikubank University, Semarang, 2015,

3 Ibid.

4 MT. Paper Two. 2004. Manual Management Book: ISM-Code. 


\section{B. RESEARCH METHODS}

Based on the problems to be studied, the research method used is normative research method, normative legal research method, which is a method used by collecting and analyzing legal materials related to the problems in this study. The legal materials used consist of primary legal materials, secondary legal materials and tertiary legal materials ${ }^{5}$.

\section{RESULTS AND DISCUSSION}

\section{Overview of the Ship}

Ships are the means most often used as a means of transportation through this water. Ships are generally used as a means of transportation to run a business. Whether it is a ship carrying or carrying goods, carrying or carrying passengers, it can even be in the form of agricultural materials (mining) or chemicals. In Article 309 KUHD defines a ship as "A ship is all boats, with any name, and of any kind". The definition of the Vollmar ship argues that the means that sail (vaartuig) is ${ }^{6}$ :

"Any object that can sail (which can move or can be moved on the water) or that thing that is meant for sailing. This is related to the existence of floating shipyards, mud dredgers, sand extractors, etc. Floating on water, these objects cannot move on their own, but can be moved even though they are not intended to be like that, but have a function as a boat (the term vaartuig translation in the KUHD) is in a certain place even though sometimes it changes places according to need ".

Then in Article 1 point 36 of Act No. 17 Year 2008 concerning Shipping, this Law defines the meaning of ships to be clearer, namely:

"Ships are vessels of certain shapes and types, which are driven by wind power, other mechanical energy energy, towed or suspended, including vehicles with dynamic support, vehicles under the surface of the water, as well as floating devices and floating structures that do not move. ${ }^{7 "}$

\section{Legal Protection for Workers on Ships}

Legal protection for workers has been described in Article $28 \mathrm{D}$ paragraph (2) of the 1945 Constitution which reads "Everyone has the right to work and to receive fair and proper compensation and treatment in a work relationship".

Legal protection for workers, both workers who work on land, in the air, and at sea, starts from the existence of a legal relationship, namely the employment relationship between the employer and the worker. Article 4 of

5 Ibid.

6 Hartanto Hartanto, Ong Argo Victoria, Anirut Chuasanga, Maritime Transportation Of Indonesian Policy, Jurnal Pembaharuan Hukum, Vol 6, No 1 (2019),

7 Bjørn-Morten Batalden \& Are Kristoffer Sydnes, Maritime safety and the ISM code: a study of investigated casualties and incidents WMU, Journal of Maritime Affairs, volume 13, page.3-25, 2014, 
Act No. 13 of 2003 concerning Manpower states that protection law for the workforce it aims to ${ }^{8}$ :

a. Empowering and empowering the use of manpower optimally and humanely,

b. Realizing equal employment opportunities and provision of employment in accordance with the needs of national and regional development,

c. Providing protection to workers in creating welfare, and

d. Improve the welfare of workers and their families.

\section{Overview of the ISM-Code}

In the General Provisions of Article 1 point 2 of Ministerial Regulation Number 45 of 2012 concerning Ship Safety Management states that the "International Safety Management (ISM) Code is the International Code concerning Ship Operation Safety Management and Pollution Prevention as regulated in Chapter IX of the 1974 SOLAS Convention which has been amended. ".

ISM-Code is a product of IMO which was finally adopted by SOLAS in 1994. ISM-Code is a safety management system standard for safe operation of ships and for prevention of pollution at sea, this ISM-Code aims to ensure safety at sea, prevent accidents or death, and also prevent damage to the environment and ships.

ISM Codeis an example of an OSH and Environmental management system standard. More or less in line with OHSAS 18001: 2007 and ISO 14001: 2004. ISM Code is not a management system standard that is run on a voluntary basis but rather is a standard for K3 and Environmental management required through laws and regulations and other requirements. In the Republic of Indonesia, the OHS management system which is clearly an obligation under the laws and regulations is the Occupational Safety and Health Management System (SMK3) which has been mandated through Government Regulation No. 50 of 2012.

The ISM-Code establishes an international standard for the management and operation of safe ships by establishing rules for shipping companies regarding safety and pollution prevention as well as for the implementation of a Safety Management System (SMS). SMS becomes the backbone for the company when it is determined and documented, duties and activities related to safety and environmental protection, both on land and on board. The existence of safe ship operating regulations is expected to prevent ship accidents so as not to harm the company concerned and the transportation users themselves. For this reason, it is necessary to have support from the company for the needs of safe ship operations, protection of the environment, and good company management by optimizing the implementation of the ISM-Code.

8 C. E. Beetham, 1995, The ISM Code - The Human Factors, International Symposium of Human Factors on Board, Bremen, Burness, Corlett \& Partners, Germany, 


\section{Implementation of the ISM-Code is used as a legal protection against the use of ships that are not standard marine standards}

ISM-Code is made as a code or guidance internationally. The ship safety management that is made aims to direct the company to be able to provide legal protection to the ship, not only to the ship but also to the workers on the ship (ship crew), the equipment on the ship, and also to the work environment (maritime environment). Of all the obligations carried out by a company based on the ISM-Code, there must be supervision in its application. ISM-Code in Indonesia has been promulgated in a legal product, namely in the Minister of Transportation Regulation Number 45 of 2012 concerning Ship Safety Management ${ }^{9}$.

The Safety Management System was created in order to comply with the requirements of IMO and the Government of the Republic of Indonesia through the Directorate General of Sea Transportation concerning Ship Safety Management Systems and Environmental Protection (ISM-Code). This Safety Management System is applied to all activities related to ship operation, including safe operation of ships and protection against pollution. Each ship must have a system and procedures for prevention and prevention of incidents of safety disturbances and in its implementation must appoint an officer who is responsible for supervising the safety of the ship and preventing pollution from the ship.

The inadequate management of ship safety from its supervisory function can be seen due to weaknesses in the management of the marine transportation system in Indonesia. So Indonesia is facing sea transportation accidents. As many as $80 \%$ of ship accidents occur due to human error, $75 \%$ of these human errors are caused by a bad management system. Therefore, a management system must be created that is able to create good and close cooperation between ship management and land management. Things like this can be used as a benchmark that the implementation of ship safety management in Indonesia is still lacking, especially in terms of supervision. Whereas in the Regulation of the Minister of Transportation Number 45 of 2012 concerning Ship Safety Management, it is clear that the duties and authorities of the company authorities are, ${ }^{10}$.

The company must establish regulations and policies related to company management and ship management that comply with the ISMCode or Ship Safety Management Regulations. Whereas the purpose and objective of ship safety management is "Ensuring that the activities on board the ship under company management meet the requirements of the Safety Management System and ensure and maintain safe shipping, paying

9 R. Amanyire, 2007, Safety Management in Shipping: An Historical Comparison to the State of the Art, M.Sc. dissertation, World Maritime University, Malmo, Sweden,

10 Kuronen, J and Tapaninen U., 2009, Maritime Safety in the Gulf of Finland - Review on policy Instruments, Publications from the Centre for Maritime Studies, University of Turku A49, 
attention to the safety of the crew, cargo, goods by making the necessary procedures".

The following are the applications mentioned in the International Safety Management Code (ISM-Code) in the 2010 Revised Edition, in paragraphs 1.3 and 1.4 , namely ${ }^{11}$ :

a. These Koda requirements can be applied to all ships;

b. Safety Management System (SMK) Requirements;

Each company must develop, implement and maintain a Safety Management System (SMK) which includes the required functions as follows:

a. Safety and environmental protection policies;

b. Instructions and procedures to ensure the safe operation of ships and protection of the environment in accordance with applicable International and National Regulations;

c. Determine the level of authority and lines of communication between and among personnel on land and on the ship;

d. Procedure for reporting accidents and non-compliance with the requirements of this code;

e. Procedures for preparation and handling of emergencies; and

f. Internal audit procedures and management review.

In implementing the ISM Code, it is used as legal protection for ships that do not meet maritime standards but are still operated by this company. Require that the supervision of all parties be increased so that they are able to carry out their duties, powers and responsibilities in accordance with the applicable laws. Through the Company's policy to comply with the elements of Article 9 of the Regulation of the Minister of Transportation Number 45 of 2012 concerning Ship Safety Management, then the reporting made by the parties on the ship to the Company, after that there is the role of the Harbormaster in overseeing the fulfillment of the ISM-Code related to shipworthiness as evidenced by the publication of documents or certificate. So that in practice the supervision carried out by the harbormaster should not only look at the legal documents by asking other people as their agents to check some of the ship's documents in order to issue SIB. Regardless of the condition of the ship which is ISM-Code standard or not by paying attention to the documents based on the completeness of the ISM-Code. This is based on good coordination or cooperation and mutual care, especially for the workers on the ship and the marine environment ${ }^{12}$.

11 F. J. Lappalainen, J. Kuronen \& U. Tapaninen, Evaluation of the ISM Code in the Finnish Shipping Companies, Journal of Maritime Research, Volume IX, No. 1, 2012, Page. 23-32,

12 Joa õ Vieira, Filipe Moura and J. M. Viegas, 2007, Transport Policy and Environmental Impacts: The Importance of Multi-instrumentality in Policy integration, Transport Policy 14, Page. 421432, 


\section{ISM-Code As Legal Protection From Use of Vessels That Are Not Marine Standard}

The legal basis for the ISM-Code is Article 169 of Act No. 17 of 2008 concerning Shipping and is further regulated by a Ministerial Regulation, namely the Minister of Transportation Regulation Number 45 of 2012 concerning Ship Safety Management. ISM-Code is a marine standard for ships both nationally and internationally. In the case of legal protection, it means talking about rights and obligations. To ensure the safety of shipping, the ISM-Code not only guarantees the safety of the ship but also the crew. This means that the rights and obligations here related to the work relationship arising from the Shipping Company are the employer / employer (ship entrepreneur) of the workers / laborers (ship crew) who work on the ship. This work relationship starts from the existence of a work agreement. Especially in shipping is sea working agreement.

To get the legal protection referred to by the crew members in a working relationship with a ship entrepreneur, it must be started from the existence of a Sea Work Agreement. In Article 395 of the Criminal Code defines a sea work agreement that "a sea work agreement is an agreement made between a ship entrepreneur on the one hand and a laborer on the other hand, whereby the party last agrees to do work for wages under the employer's order, as a captain or a child".

Article 1338 of the Civil Code explains that "All agreements that are legally made are valid as laws for those who make them". An agreement in civil law is something that is fundamental and can be said as law for the maker, it can be said that the agreement is a form of legal protection for the parties in carrying out the agreement ${ }^{13}$.

ISM-Code will not run well if it is not fully implemented and the most important thing is the supervisory function of the implementation whether it has been fulfilled or not. Supervision is the most important part in Management. Without the supervision and care of various parties, the original goals or plans of the organization cannot be achieved. ISM-Code or Ship Safety Management is also a legal protection not only for the ship but also for the crew. There are several reasons for running ISM-Code including:

a. ISM-Code makes ships a safe place to work;

b. ISM-Code protects the sea and the environment / water areas;

c. ISM-Code defines tasks clearly;

d. The ISM-Code is legal.

The legal protection provided by the ISM-Code is that it defines the duties of the parties clearly, meaning that the rights and obligations of each party have been regulated in good safety management. In letters $b$ and $d$ Article 9 of the Regulation of the Minister of Transportation 45 of 2012

13 R. Greiner, M. D. Young, A. D. McDonald \& M. Brooks, Incentive Instruments for the Sustainable use of Marine Resources, Ocean \& Coastal Management, 2000, 43(1), Page. 29-50, 
concerning Ship Safety Management states that there are responsibilities and authorities of the Authority on land (the Company) and the responsibility and authority of the Authority on board the ship (Capten). Besides defining the duties of the company, the ISM-Code also ensures that the company provides adequate support to its workers. Support can be in the form of good work equipment and social security that must be provided to workers so that workers can work safely and prosperously. ${ }^{14}$.

Legally, the purpose of the ISM-Code or Ship Safety Management is stated as referred to in Article 7 of the Minister of Transportation Regulation Number 45 of 2012 concerning Ship Safety Management states that the purpose of a safety management system is to:

a. Provide practical work procedures in operating ships safely and a safe working environment,

b. Assess all risk identification to the ship, personnel, environment and determine preventive actions, and

c. Continuously improving the skills of personnel on land and on board in the field of safety management, including preparedness for emergency situations related to safety and environmental protection.

The function of the ISM-Code is as legal protection for ships that do not meet maritime standards but are still operated by the company according to the purpose of the ISM-Code itself. That the ISM-Code clearly defines the duties between parties. The law has stipulated the requirements that must be done and fulfilled by shipping companies or it can be said that the ISM-Code defines the duties, authorities and responsibilities of each party and states the rights that must be received and the obligations that must be carried out in the working relationship. However, in this case the aspect of supervision should not be abandoned, supervision is carried out for the efficiency and effectiveness of Ship Safety Management to run and be implemented properly. ${ }^{15}$.

Based on these aspects the ISM-Code is an international management standard which is a safety management that must be implemented on ships as well as in companies with a purpose ${ }^{16}$ :

a. Ensuring the safety of the ship and its crew.

b. Prevent accidents and casualties on board.

c. Prevent environmental pollution, environmental damage and loss of property.

So that in Article 8 of the Regulation of the Minister of Transportation Number 45 Years

2012 About Ship Safety Management. The safety management system must ensure:

14 P. Anderson, 2003, Cracking the Code - The Relevance of the ISM Code and its Impacts on Shipping Practices, The Nautical Institute, London;

15 Kit Fai Pun, Richard C. M. Yam, and Winston G. Lewis, Op.cit. 16 Ibid. 
a. Fulfillment of mandatory rules and regulations,

b. Codes, guidelines, and standards recommended by the Organization

The International Maritime Organization (IMO), the Government, Classification Bodies, and the applicable Maritime Industry Organizations are also considered.

\section{CONCLUTION}

In the application of the ISM-Code, it is used as a legal protection from the use of ships that are not standard marine standards. There are still many shipping companies that issue policies that are not standard ISM-Code or do not meet the elements of Article 9 of the Minister of Transportation Regulation Number 45 of 2012 concerning Ship Safety Management Systems. The implementation of the ISM-Code starts with a company policy called Shipping Safety. The ISM-Code is needed as legal protection from the use of ships that do not meet maritime standards, which is from the form of legal protection contained in the ISM-Code, namely from clearly defining the duties of the parties. Which means there is a division of duties, authorities and responsibilities of each party on the ship and the company. From the division of tasks, it means that there is a working relationship that makes the rights and obligations of each party clear. In addition, safety is very important in a job, be it work on land, sea or anywhere.

Ensuring safety is also very important and must be done by every individual who will carry out an activity. Safety in a voyage is a major part in terms of sea transportation and crossing, which requires that all ships that will operate must meet the safety standards themselves. Ensuring safety is also very important and must be done by every individual who will carry out an activity. Safety in a voyage is a major part in terms of sea transportation and crossing, which requires that all ships that will operate must meet the safety standards themselves. Ensuring safety is also very important and must be done by every individual who will carry out an activity. Safety in a voyage is a major part in terms of sea transportation and crossing, which requires that all ships that will operate must meet the safety standards themselves.

\section{Books:}

\section{BIBLIOGRAPHY}

C. E. Beetham, 1995, The ISM Code-The Human Factors, International Symposium of Human Factors on Board. Bremen, Burness, Corlett \& Partners, Germany;

MT. Paper Two. 2004. Manual Management Book, ISM-Code.

P. Anderson, 2003, Cracking the Code-The Relevance of the ISM Code and its Impacts on Shipping Practices, The Nautical Institute, London; 
R. Amanyire, 2007, Safety Management in Shipping: An Historical Comparison to the State of the Art, M.Sc. dissertation, World Maritime University, Malmo, Sweden;

\section{Journals:}

F. J. Lappalainen, J. Kuronen \& U. Tapaninen, Evaluation of the ISM Code in the Finnish Shipping Companies, Journal of Maritime Research, Volume IX, No. 1, 2012;

Joa õ Vieira, Filipe Moura and J. M. Viegas, Transport Policy and Environmental Impacts: The Importance of Multi-instrumentality in Policy integration, Transport Policy 14, 2007;

Kit Fai Pun, Richard C. M. Yam, and Winston G. Lewis, Safety Management System Registration in the Shipping Industry, International Journal of Quality \& Reliability Management, Volume 20, Issue 6, 2002;

Kuronen, J and Tapaninen U., Maritime Safety in the Gulf of Finland - Review on policy Instruments, Publications from the Centre for Maritime Studies, University of Turku A49, 2009;

Nina Nurhasanah, Asmar Joni, and Nur Shabrina. Perception of Crew and Management in the Implementation of ISM-Code for Shipping Safety and Protection of the Marine Environment, National Multi Discipline Seminar and Call For Papers, Stikubank University. Semarang, 2015;

R. Greiner, M. D. Young, A. D. McDonald \& M. Brooks, Incentive Instruments for the Sustainable use of Marine Resources. Ocean \& Coastal Management, 2000, 43(1); 